\title{
CEBER
}

CENTRE FOR BUSINESS AND ECONOMICS RESEARCH

UNIVERSITY OF COIMBRA

\section{Renewable Energy Consumption and Economic Growth: a note reassessing panel data results}

\author{
Regina Maria Marques da Fonseca Pereira \\ University of Coimbra, Faculty of Economics \\ Tiago Miguel Guterres Neves Sequeira \\ University of Coimbra, Centre for Business and Economics Research, CeBER and \\ Faculty of Economics \\ Pedro André Ribeiro Madeira Cunha Cerqueira \\ University of Coimbra, Centre for Business and Economics Research, CeBER and \\ Faculty of Economics
}

CeBER Working Papers

No. 10 / 2020 


\title{
Renewable Energy Consumption and Economic Growth: a note reassessing panel data results*
}

\author{
Regina Pereira ${ }^{1}$,Tiago Sequeira ${ }^{2, *}$ and Pedro Cerqueira ${ }^{2}$ \\ ${ }^{1}$ Univ Coimbra, Faculty of Economics, Av Dias da Silva 165, 3004-512 Coimbra \\ ${ }^{2}$ Univ Coimbra, CeBER, Faculty of Economics, Av Dias da Silva 165, 3004-512 Coimbra \\ *E-mail: tiago.n.sequeira@fe.uc.pt
}

\begin{abstract}
We contribute to the renewable energy consumption-income (and growth) nexus literature by performing an empirical study on a worldwide panel data, also accounting for cross-country dependency using a parsimonious specification that accounts for traditional sources of income differences as well as institutional features of the countries. Our results present either negative or nonsignificant influence of the share of renewable energies consumption to economic growth and income.
\end{abstract}

Keywords: renewable energy consumption, economic growth regressions, economic growth JEL Codes: O40, Q21, Q43

* This paper is an improved version of a work initiated in the Applied Econometrics course of the Economics Undergraduate program in the Faculty of Economics, University of Coimbra, Portugal.

${ }^{2}$ Authors acknowledge funded by national funds through FCT - Fundação para a Ciência e a Tecnologia, I.P., Project UIDB/05037/2020 


\section{Introduction}

Despite the great upsurge of studies on the relationship between renewable energy (consumption and production) and economic growth, the previous literature has been shown to be inconclusive showing different sign and causality directions, with prevalence for positive significant results.

According to Ozturk (2010), in a review of the literature on the energy consumption-growth nexus, these differing results mostly affecting causality directions are due to the use of different data set, econometric methodologies and countries' characteristics. There are country-specific (e.g. Long et al., 2012, in a study for China) and multi-country studies on the energy-consumption growth nexus (for instance, Alper and Oguz (2016) and Armeanu et al. (2017) for EU countries, Bhattacharya et al. (2016) for the 38 countries that consume more energy, Inglesi-Lotz (2016) for OECD countries, Chang et al. (2015) for G7 countries). All these studies on the consumption-growth nexus showed positive influence of renewable consumption share in economic growth or income.

It is important to mention as well that the research of the impact of energy production on the economic growth (e.g. Marques and Fuinhas (2012), and Singh et al. (2019)) is also part of this discussion. While Marques and Fuinhas (2012) discovered a negative influence of the share renewable energy production on economic growth arguing that the opportunity costs of supporting them are higher than the positive effect they may have on income, Singh et al. (2019) found a positive relationship, reinforcing the idea, already mentioned by Ozturk (2010) that contradictory results mostly depends on specification and econometric methods. Throughout this article we rely on the energy-consumption perspective.

The causality direction is important as far as we know that richer countries tend to adopt more modern renewable energy sources - which works in the inverse causality direction to the influence of renewable energy on growth --, as argued e.g. by Burke (2010) and Ramalho et al. (2018). Most papers on the renewable consumption or production-nexus use methods that are robust to reverse causality (an exception is Marques and Fuinhas, 2012). Most of them failed to include typical sources of income differences in regressions - e.g. physical and human capital, government current expenditures, and so on (an exemption is Inglesi-Lotz (2016), who include controls such as employment and physical capital). 
Concerning the country-specific studies, Long et al. (2012) examine the role of energy consumption, carbon emissions and economic growth applying Granger causality analysis. Their conclusions mention that hydro and nuclear power have positive impact on economic growth even though, coal has a dominant impact.

Regarding the multi-country studies, Alper and Oguz (2016) apply an asymmetric causality test approach and an autoregressive distributed lag (ADRL) approach, using the time period 1990-2009 for Bulgaria, Cyprus, Czech Republic, Estonia, Hungary, Poland, Romania, and Slovenia. The results establish a positive impact of renewable energy consumption on economic growth, however, only for Bulgaria, Estonia, Poland and Slovenia they verified a statistically significant impact. Bhattacharya et al. (2016) investigate this matter using panel estimation techniques for 38 major renewable energy consuming countries in the world to explain the economic growth between 1991 and 2012, confirming that in 57\% of those countries was verified a positive impact of RE on Economic growth. This is the unique of the reviewed articles that deals with well-known issues in macroeconomic empirical studies using panel data (cross-country dependence and heterogeneity between countries). In fact, as shown by Eberhardt and Teal (2011), with the presence of cross-country dependence, individual countries cannot be viewed as independent cross-sections. In our most robust regressions we will use common correlated effects (CCE) estimators which take into account the fact that renewable energy consumption and GDP variables are highly correlated across countries and the possibility of heterogeneous effects of energy consumption in income and growth.

We complement the existing literature in three main directions: (i) we use a wider panel data of countries between 1960 to 2018; (ii) we use a parsimonious specification avoiding obvious omitted variables bias due to omission of typical determinants of economic growth as well as institutional determinants of income differences; (iii) we apply more recent panel data methods with heterogeneity of coefficient and common effects, as it has been used in the most recent empirical literature of economic growth. Our results present either negative or nonsignificant influence of the share of renewable energies consumption to economic growth and income.

In the following Section we describe our data and methods. In Section 3, we present the results from regressions. Section 4 concludes. 


\section{Data and Methods}

In order to interpret the impact of renewable energies consumption on economic growth, we implemented four slightly different models - which also allowed us to test for robustness for the period of 1960 to 2018 (59 years) using panel data analysis. GDP per capita plays the role of dependent variable and, with the purpose of compare results, we resort to two different data bases: one from the World Bank DataBank (WB) and the other from Penn World Tables (PWT). This means that in these initial regressions we are estimating income regressions, which are important for understanding income differences between countries. ${ }^{1}$

For the explanatory variables, we employ World Bank data and we selected the estimates of the Governance Indicators (Control of Corruption (Corrupt), Governance Effectiveness (Gov.Eff), Political Stability and Absence of Violence/Terrorism (Gov.St), Regulatory Quality (Gov.Q), Rule of Law (R.Law), Voice and Accountability (Gov.Ac)), the Share of Renewable Energy Consumption as the percentage of the total final energy consumption (RE share) - which is our variable of interest - the General Government Final Consumption Expenditure as a percentage of GDP (Gov.Con), the annual percentage growth of Gross Capital Formation (Inv), and Gross Savings as the percentage of GDP (Savings) as two different proxies for physical capital accumulation and the Total Lower Secondary Completion rate as a percentage of relevant age group (Sec.Att) and the gross percentage of Secondary Enrolment (Sec. Enr), as two different proxies for human capital accumulation.

Additionally we estimate two specification types - in one we implement lags of one time period in the explanatory variables while in the other we do not. That said, the main regression is expressed, in a log-linear specification, as follows: ${ }^{2}$

$$
\begin{aligned}
& \log y_{i t}=\beta_{0}+\beta_{1} \text { Corrupt }_{i, t-1}+\beta_{2} \text { Gov. Eff }_{i, t-1}+\beta_{3} \text { Gov.St } t_{i, t-1}+\beta_{4} \text { R. Law } \text { Law }_{i, 1}+ \\
& \beta_{5} \text { Gov. } A c_{i, t-1}+\text { Gov. } Q_{i, t-1}+\beta_{6} R E \text { share }_{i, t-1}+\beta_{7} e d u_{i, t-1}+\beta_{8} \text { inv }_{i, t-1}+
\end{aligned}
$$

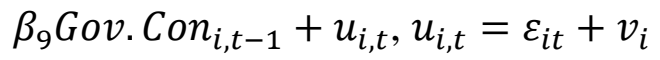

Where $y$ is GDP per capita from the Penn World Tables (PWT) - measured as Output-side real GDP at chained PPPs 2011 USD -- or the World Bank (WB) - at constant 2010 USD. Depending on the different presented specifications, edu stands for total Lower Secondary Completion rate or Secondary School Enrolment and inv is Gross Capital Formation or Gross

\footnotetext{
${ }^{1}$ It also avoids the well-known Nickel (1981) bias that affects fixed-effect estimation of an equation with a lagged dependent variable.

${ }^{2}$ The equation represents the specification with lagged explanatory variables. To write the specification with all variables dated in the same time $t$, substitute the $(t-1)$ in that equation by $(t)$ in each index.
} 
Savings, also depending on different specification. Moreover, $v_{i}$ is the country-specific (nonobserved) effect that can be correlated with the error term $\varepsilon_{i t}$.

Least Squares Dummy Variable (LSDV) estimation is robust to country-specific effects and allows for possible correlation between country effects and the error term. These features make the method the most panel data approach to deal with macroeconomic data. Our first regression results are from LSDV estimation (see below Tables 2 and 3). However, it imposes parameter homogeneity (i.e. the effects of the explanatory variables on the dependent variable is common for all countries), an assumption increasingly criticized by macroeconomists. Moreover it also assumes cross-country independence, a highly implausible assumption.

In additional evidence provided in Section 3.1, the specification is augmented by (i) common (non-observed) factors that are year-specific $\left(\boldsymbol{f}_{\boldsymbol{t}}\right)$ and (ii) heterogeneous parameters. The factors intend to represent common factors affecting all the countries at a given year and are included as cross-averages of the explanatory variables. In that case, the alternative equation may be specified as:

$$
\begin{aligned}
& g\left(y_{i t}\right)=
\end{aligned}
$$

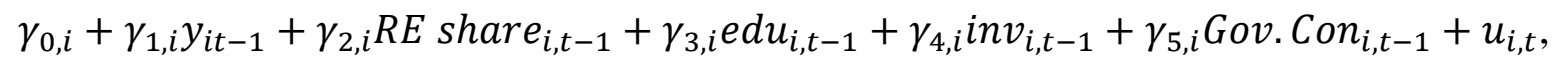

$$
\begin{aligned}
& u_{i, t}=\varepsilon_{i t}+\boldsymbol{f}_{t},
\end{aligned}
$$

in which $g\left(y_{i t}\right)$ is the growth rate of real GDP per capita and institutional variables are omitted due to the fact that they are quite stable within countries. ${ }^{3}$ As a result of that, the number of cross-sectional units varies from model to model depending on the source of the dependent variable and the proxy that it is used in each regression for investment in physical and human capital. Regressions where $y$ is GDP per capita from PWT the number of countries in the sample varies between 136 (when we use gross capital formation and total lower secondary completion rate as proxies for physical and human capital, respectively) and 145 (when we use Gross Savings and Secondary School Enrolment as proxies for physical and human capital).. In the other hand, on the regression where $y$ is GDP per capita from WB the number of countries ranges from 147 countries in the first case to 161 in the second case.

Descriptive statistics for the main variables are presented in Table 1.

\footnotetext{
${ }^{3}$ More motivation and details on the method are given in Section 3.1.
} 
Table 1 -Descriptive statistics of variables in Equation (1)

\begin{tabular}{|c|c|c|c|c|c|}
\hline & $\begin{array}{c}(1) \\
\text { count }\end{array}$ & $\begin{array}{c}(2) \\
\text { mean }\end{array}$ & $\begin{array}{l}\text { (3) } \\
\text { sd }\end{array}$ & $\begin{array}{c}(4) \\
\min \end{array}$ & $\begin{array}{c}(5) \\
\max \end{array}$ \\
\hline RE share & 5144 & 31.89335 & 31.20721 & 0 & 98.3426 \\
\hline y PWT & 8536 & 12899.14 & 31479.44 & 131.3002 & 792461.3 \\
\hline$y$ WB & 9160 & 11604.09 & 18362.41 & 132.3032 & 193745.6 \\
\hline Corrupt & 4006 & -.0146231 & .9959661 & -1.868714 & 2.469991 \\
\hline Gov.Eff & 3998 & -.0177132 & .9894439 & -2.445876 & 2.436975 \\
\hline Gov.St & 4016 & -.0152651 & .9941213 & -3.314937 & 1.965062 \\
\hline Gov.Q & 3998 & -.0170544 & .9929139 & -2.645041 & 2.260543 \\
\hline R.Law & 4065 & -.0167718 & .9932763 & -2.606445 & 2.100273 \\
\hline Gov.Ac. & 4040 & -.0147541 & .9963912 & -2.313395 & 1.800992 \\
\hline Gov.Con & 7787 & 15.83033 & 7.154148 & 0 & 135.8094 \\
\hline inv (Investment) & 5385 & 21.23719 & 12.21288 & -236.2275 & 100.6717 \\
\hline edu (Attainment) & 6026 & 7.072774 & 45.08355 & -376.2229 & 2820.37 \\
\hline inv (Savings) & 3719 & 61.8388 & 32.26739 & .23963 & 141.8758 \\
\hline edu (Enrollment) & 6153 & 64.41871 & 34.13238 & 0 & 166.1359 \\
\hline$N$ & 10584 & & & & \\
\hline
\end{tabular}

\section{Results}

In this Section, we present our main results. First, in order to test for different specifications we present different regressions based on LSDV estimation using alternative data sources for the dependent variable (Penn World Tables and World Bank) and for some of the most important proxies for the proximate determinants of economic growth (savings and investment in alternative regressions and secondary attainment and secondary enrolment in alternative regressions).. Tables 2 and 3 present these regressions. While Table 2 presents the results for the specification in which the explanatory variables are entered in the same period as the dependent variable, Table 3 presents the results for the specification in which the explanatory variables are entered with one lag (see equation (1)). The F-test clearly rejects the null according to which all the specific country effects would be zero and then validates the fixed-effects approach vis-à-vis pooled OLS. The Hausman test consistently rejects the null according to which the alternative random effects estimation would be appropriate. Both tests lead to the choosing fixed-effects or LSDV estimation.

It is important to note that crucial institutional determinants of income differences such as Government Stability, Government Effectiveness, Government Quality, Rule of Law have the expected positive sign (see e.g. Hall and Jones, 1999 and Acemoglu, Johnson, and 
Robinson, 2005). Also, Government Consumption is significantly and negatively associated to income per capita as is typical in growth and income regressions (for the seminal reference see Barro, 1991). Moreover, while investment and educational attainment in the secondary level of education tend to be nonsignificant, the alternative proxies, savings and enrolment in secondary education, tend to be significant and positive.

The most robust and interesting result is the strongly significant negative sign of the share of renewable energy consumption on income differences, which is quite stable across different specifications, namely with the use of different controls for physical and human capital and both when explanatory variables enter in the same period as the dependent variable and when explanatory variables enter with a lag of one year. In this case one additional percent point in the share of renewable energy consumption would result in $0.5 \%$ to $0.8 \%$ decrease in GDP per capita, a sizeable effect. ${ }^{4}$

\footnotetext{
${ }^{4}$ In alternative growth regressions (in which a lag of the dependent variable is included in the explanatory variables set), the result is the same as the one reported in Tables 2 and 3: there is a strong negative statistically significant effect of rene wable energy consumption on economic growth. Results are available upon request.
} 
Table 2: Fixed Effect Regressions with time Effects (No lag in explanatory variables)

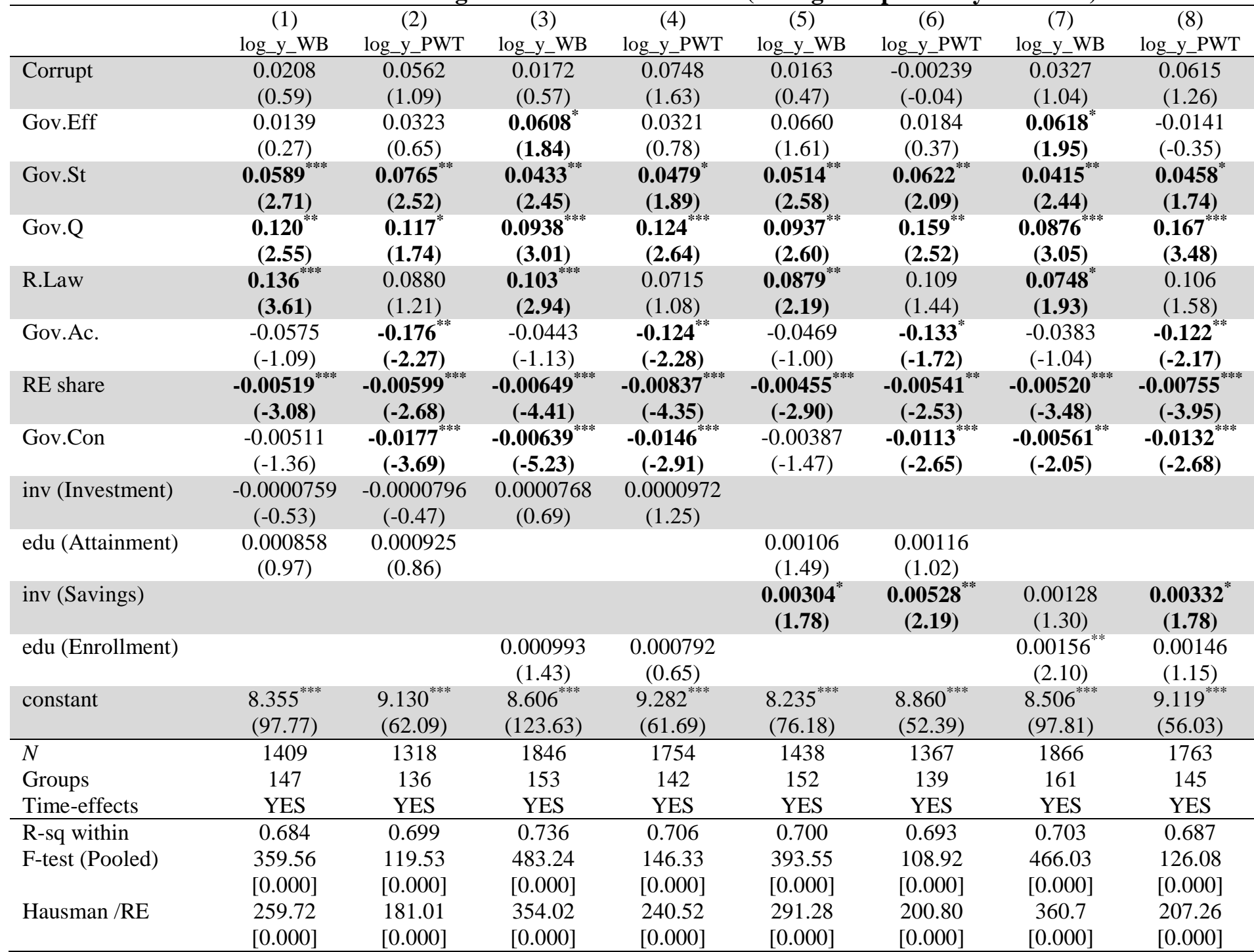

$t$ statistics based on heteroscedastic-consistent variance-covariance matrix in parentheses. For the tests, p-values are in squared brackets.

${ }^{*} p<0.1,{ }^{* *} p<0.05,{ }^{* * *} p<0.01$. Significant results are highlighted in bold. 
Table 3: Fixed Effect Regressions with time Effects (with lag in explanatory variables)

\begin{tabular}{|c|c|c|c|c|c|c|c|c|}
\hline & $\begin{array}{c}(1) \\
\log \_y \_W B\end{array}$ & $\begin{array}{c}(2) \\
\log \_y \_P W T\end{array}$ & $\begin{array}{c}(3) \\
\log { }_{-} y_{-} W B\end{array}$ & $\begin{array}{c}(4) \\
\log _{-} \mathrm{y}_{-} \mathrm{PWT}\end{array}$ & $\begin{array}{c}(5) \\
\log _{-} \mathrm{y}_{-} \mathrm{WB}\end{array}$ & $\begin{array}{c}(6) \\
\log _{-} y_{-} P W T \\
\end{array}$ & $\begin{array}{c}(7) \\
\log { }_{-}{ }_{-} W B\end{array}$ & $\begin{array}{c}(8) \\
\log _{-} y_{-} \text {PWT }\end{array}$ \\
\hline Corrupt & $\begin{array}{c}0.0182 \\
(0.51)\end{array}$ & $\begin{array}{c}0.0485 \\
(0.92)\end{array}$ & $\begin{array}{c}0.0286 \\
(0.93)\end{array}$ & $\begin{array}{c}0.0813 \\
(1.76)\end{array}$ & $\begin{array}{c}0.0148 \\
(0.39)\end{array}$ & $\begin{array}{c}0.00219 \\
(0.04)\end{array}$ & $\begin{array}{c}0.0358 \\
(1.11)\end{array}$ & $\begin{array}{c}0.0694 \\
(1.42)\end{array}$ \\
\hline Gov.Eff & $\begin{array}{c}0.0322 \\
(0.64)\end{array}$ & $\begin{array}{c}0.0323 \\
(0.64)\end{array}$ & $\begin{array}{c}0.0756^{* *} \\
(2.23)\end{array}$ & $\begin{array}{l}0.0423 \\
(1.02)\end{array}$ & $\begin{array}{c}0.0716^{*} \\
(1.73)\end{array}$ & $\begin{array}{c}0.0198 \\
(0.40)\end{array}$ & $\begin{array}{c}0.0660^{* *} \\
(2.04)\end{array}$ & $\begin{array}{c}-0.00704 \\
(-0.18)\end{array}$ \\
\hline Gov.St & $\begin{array}{c}0.0544^{* * * *} \\
(2.74)\end{array}$ & $\begin{array}{c}0.0686 \\
(2.28)\end{array}$ & $\begin{array}{c}0.0425^{* *} \\
(2.45)\end{array}$ & $\begin{array}{l}0.0393 \\
(1.57)\end{array}$ & $\begin{array}{c}0.0458^{* *} \\
(2.60)\end{array}$ & $\begin{array}{c}0.0461^{*} \\
(1.67)\end{array}$ & $\begin{array}{c}0.0413^{* *} \\
(2.55)\end{array}$ & $\begin{array}{c}0.0301 \\
(1.21)\end{array}$ \\
\hline Gov.Q & $\begin{array}{c}0.113^{* *} \\
(2.52)\end{array}$ & $\begin{array}{l}0.132^{* *} \\
(2.05)\end{array}$ & $\begin{array}{c}0.0862^{* * * *} \\
(2.83)\end{array}$ & $\begin{array}{c}0.130^{* * * *} \\
(3.00)\end{array}$ & $\begin{array}{c}0.0884^{* *} \\
(2.52)\end{array}$ & $\begin{array}{c}0.164^{* * * *} \\
(2.71)\end{array}$ & $\begin{array}{c}0.0885^{* * * *} \\
(3.13)\end{array}$ & $\begin{array}{c}0.169^{* * * *} \\
(3.71)\end{array}$ \\
\hline R.Law & $\begin{array}{c}0.104^{* * *} \\
(2.88)\end{array}$ & $\begin{array}{l}0.0493 \\
(0.75)\end{array}$ & $\begin{array}{c}0.0820^{* *} \\
(2.46)\end{array}$ & $\begin{array}{l}0.0427 \\
(0.69)\end{array}$ & $\begin{array}{c}0.0576 \\
(1.49)\end{array}$ & $\begin{array}{c}0.0715 \\
(1.04)\end{array}$ & $\begin{array}{c}0.0414 \\
(1.14)\end{array}$ & $\begin{array}{c}0.0740 \\
(1.19)\end{array}$ \\
\hline Gov.Ac. & $\begin{array}{c}-0.0231 \\
(-0.50)\end{array}$ & $\begin{array}{c}-0.0922 \\
(-1.17)\end{array}$ & $\begin{array}{c}-0.0343 \\
(-1.00)\end{array}$ & $\begin{array}{c}-0.0783 \\
(-1.31)\end{array}$ & $\begin{array}{c}-0.00584 \\
(-0.15)\end{array}$ & $\begin{array}{c}-0.0524 \\
(-0.75)\end{array}$ & $\begin{array}{c}-0.0152 \\
(-0.47)\end{array}$ & $\begin{array}{c}-0.0694 \\
(-1.20)\end{array}$ \\
\hline RE share & $\begin{array}{c}-0.00491^{* * * *} \\
(-2.98)\end{array}$ & $\begin{array}{c}-0.00658^{* * * *} \\
(-2.87)\end{array}$ & $\begin{array}{c}-0.00602^{* * * *} \\
(-3.92)\end{array}$ & $\begin{array}{c}-0.00885^{* * * *} \\
(-4.46)\end{array}$ & $\begin{array}{c}-0.00464^{* * * *} \\
(-2.98)\end{array}$ & $\begin{array}{c}-0.00628 \\
(-2.92)\end{array}$ & $\begin{array}{c}-0.00527^{* * * * *} \\
(-3.47)\end{array}$ & $\begin{array}{c}-0.00808^{* * * *} \\
(-4.23)\end{array}$ \\
\hline Gov.Con & $\begin{array}{c}-0.00507 \\
(-1.44)\end{array}$ & $\begin{array}{c}-0.0175^{* * * *} \\
(-3.61)\end{array}$ & $\begin{array}{c}-0.00565^{* * * *} \\
(-5.30)\end{array}$ & $\begin{array}{c}-0.0137^{* * * *} \\
(-2.81)\end{array}$ & $\begin{array}{c}-0.00352 \\
(-1.52)\end{array}$ & $\begin{array}{c}-0.0104 \\
(-2.54)\end{array}$ & $\begin{array}{c}-0.00551^{* * *} \\
(-2.25)\end{array}$ & $\begin{array}{c}-0.0120 \\
(-2.54)\end{array}$ \\
\hline inv (Investment) & $\begin{array}{c}0.0000162 \\
(0.11)\end{array}$ & $\begin{array}{c}0.0000756 \\
(0.38)\end{array}$ & $\begin{array}{c}0.000167 \\
(1.36)\end{array}$ & $\begin{array}{c}0.000288 \\
(2.46)\end{array}$ & & & & \\
\hline edu (Attainment) & $\begin{array}{c}0.00107 \\
(1.31)\end{array}$ & $\begin{array}{c}0.000735 \\
(0.69)\end{array}$ & & & $\begin{array}{c}0.00102 \\
(1.48)\end{array}$ & $\begin{array}{c}0.00107 \\
(0.96)\end{array}$ & & \\
\hline inv (Savings) & & & & & $\begin{array}{c}0.00352^{* * *} \\
(2.01)\end{array}$ & $\begin{array}{c}0.00566 \\
(2.23)\end{array}$ & $\begin{array}{c}0.00185^{*} \\
(1.86)\end{array}$ & $\begin{array}{c}0.00417^{* *} \\
(2.44)\end{array}$ \\
\hline edu (Enrollment) & & & $\begin{array}{c}0.00126 * \\
(1.89)\end{array}$ & $\begin{array}{c}0.000887 \\
(0.77)\end{array}$ & & & $\begin{array}{c}0.00179 \\
(2.47)\end{array}$ & $\begin{array}{c}0.00175 \\
(1.45)\end{array}$ \\
\hline _cons & $\begin{array}{l}8.363^{* * *} \\
(97.16)\end{array}$ & $\begin{array}{l}9.167^{* * *} \\
(65.70)\end{array}$ & $\begin{array}{l}8.594^{* * * *} \\
(121.86)\end{array}$ & $\begin{array}{l}9.286^{* * *} \\
(65.66)\end{array}$ & $\begin{array}{l}8.250^{* * *} \\
(74.69)\end{array}$ & $\begin{array}{l}8.883^{* * *} \\
(52.14)\end{array}$ & $\begin{array}{l}8.508^{* * *} \\
(97.51)\end{array}$ & $\begin{array}{l}9.088^{* * *} \\
(58.06)\end{array}$ \\
\hline$N$ & 1407 & 1318 & 1844 & 1754 & 1437 & 1367 & 1864 & 1763 \\
\hline Groups & 147 & 136 & 153 & 142 & 152 & 139 & 161 & 145 \\
\hline Time-effects & YES & YES & YES & YES & YES & YES & YES & YES \\
\hline R-sq within & 0.675 & 0.672 & 0.727 & 0.693 & 0.692 & 0.675 & 0.699 & 0.678 \\
\hline F-test (Pooled) & $\begin{array}{c}371.32 \\
{[0.000]}\end{array}$ & $\begin{array}{c}114.66 \\
{[0.000]}\end{array}$ & $\begin{array}{l}490.54 \\
{[0.000]}\end{array}$ & $\begin{array}{c}143.65 \\
{[0.000]}\end{array}$ & $\begin{array}{l}402.87 \\
{[0.000]}\end{array}$ & $\begin{array}{c}106.85 \\
{[0.000]}\end{array}$ & $\begin{array}{c}469.6 \\
{[0.000]}\end{array}$ & $\begin{array}{c}123.32 \\
{[0.000]}\end{array}$ \\
\hline Hausman /RE & $\begin{array}{l}264.95 \\
{[0.000]}\end{array}$ & $\begin{array}{l}174.96 \\
{[0.000]}\end{array}$ & $\begin{array}{l}354.14 \\
{[0.000]}\end{array}$ & $\begin{array}{l}230.00 \\
{[0.000]}\end{array}$ & $\begin{array}{l}292.55 \\
{[0.000]}\end{array}$ & $\begin{array}{l}186.47 \\
{[0.000]}\end{array}$ & $\begin{array}{l}365.36 \\
{[0.000]}\end{array}$ & $\begin{array}{l}192.28 \\
{[0.000]}\end{array}$ \\
\hline
\end{tabular}

$t$ statistics based on heteroscedastic-consistent variance-covariance matrix in parentheses. For the tests, p-values are in squared brackets.

${ }^{*} p<0.1,{ }^{* *} p<0.05,{ }^{* * *} p<0.01$. Significant results are highlighted in bold. 


\subsection{Accounting for cross country dependency and heterogeneity}

However, as shown by Eberhardt and Teal (2011), with the presence of cross-country dependence, individual countries cannot be viewed as independent cross-sections, as has been assumed in almost all of the empirical literature reporting on the relationship between income and democracy. Cross-section dependence can affect both inference and identification (see Bailey, Kapetanios, and Pesaran 2015; Pesaran 2015). The most obvious implication of error cross-sectional dependence is that standard panel data estimators are inefficient and estimated standard errors are biased and inconsistent.Therefore, error cross-sectional dependence can also induce a bias and even result in inconsistent estimates. In general, inconsistency arises as an omitted-variables bias when the observed explanatory variables are correlated with the unobserved common factors (see, e.g. Pesaran 2006). Another important issue that arises in panel databases with a large time-series dimension is non-stationarity of variables. This is another neglected feature of data in reported estimations in this literature. As Eberhardt and Teal (2011) observe, "The standard empirical estimators (e.g. fixed effects, difference and system GMM) not only impose homogeneous production technology, but they also implicitly assume stationarity, cross-sectionally independent, variables". We will use the Pesaran (2006) common correlated effects mean group estimator to address our empirical objective. One of the important features of this estimator in comparison to other panel data estimators is that it is robust to country-fixed effects such as geography and culture, and initial technology level, and to unobservable common variables such as common productivity and institutional change and common trends in renewable energy consumption. Because of that we avoid including institutional variables that tend to vary less throughout time. Besides correcting for possibly omitted common factors and heterogeneity, it is appropriated to deal with a clearly unbalanced panel like this one. Furthermore because there is no bias introduced by using lagged values of the dependent variable, here we use the growth of real GDP per capita as the dependent variable and not the level of GDP per capita as we did in Table 2.

Many authors reported the nonstationarity of GDP per capita and its cross-country dependency (see e.g. Eberhardt and Teal, 2011 and Sequeira, 2017).

We also run Pesaran (2007) unit root tests and concluded that both GDP per capita and renewable energy consumption share are I(1); Kao (1999) and Westerlund (2005) 
cointegration tests that reject the null of no cointegration between GDP per capita and renewable energy share, and Pesaran (2004) cross-country independency is clearly rejected. ${ }^{5}$

This gives support for our robust approach following common correlated estimator but also to build an adequate error correction model (ECM). ${ }^{6}$ Results are presented in Table 4. In columns (1) to (4), we present results from the common correlated estimator and in columns (5) to (8), we present results from the corresponding ECM. The dependent variable is the growth rate of per capita GDP from PWT in columns (1) and (2), (5) and (6) and from WB in columns (3) and (4), (7) and (8). Moreover, an outliers-robust variance-covariance matrix is used to obtain the standard-errors in columns (2), (4), (6) and (8).

\footnotetext{
${ }^{5}$ A Table with the results is on the Appendix.

${ }^{6}$ This was also the approach followed by Eberhardt and Prebistero (2015) and Sequeira (2017).
} 
Table 4: Common Correlated Effects Regressions

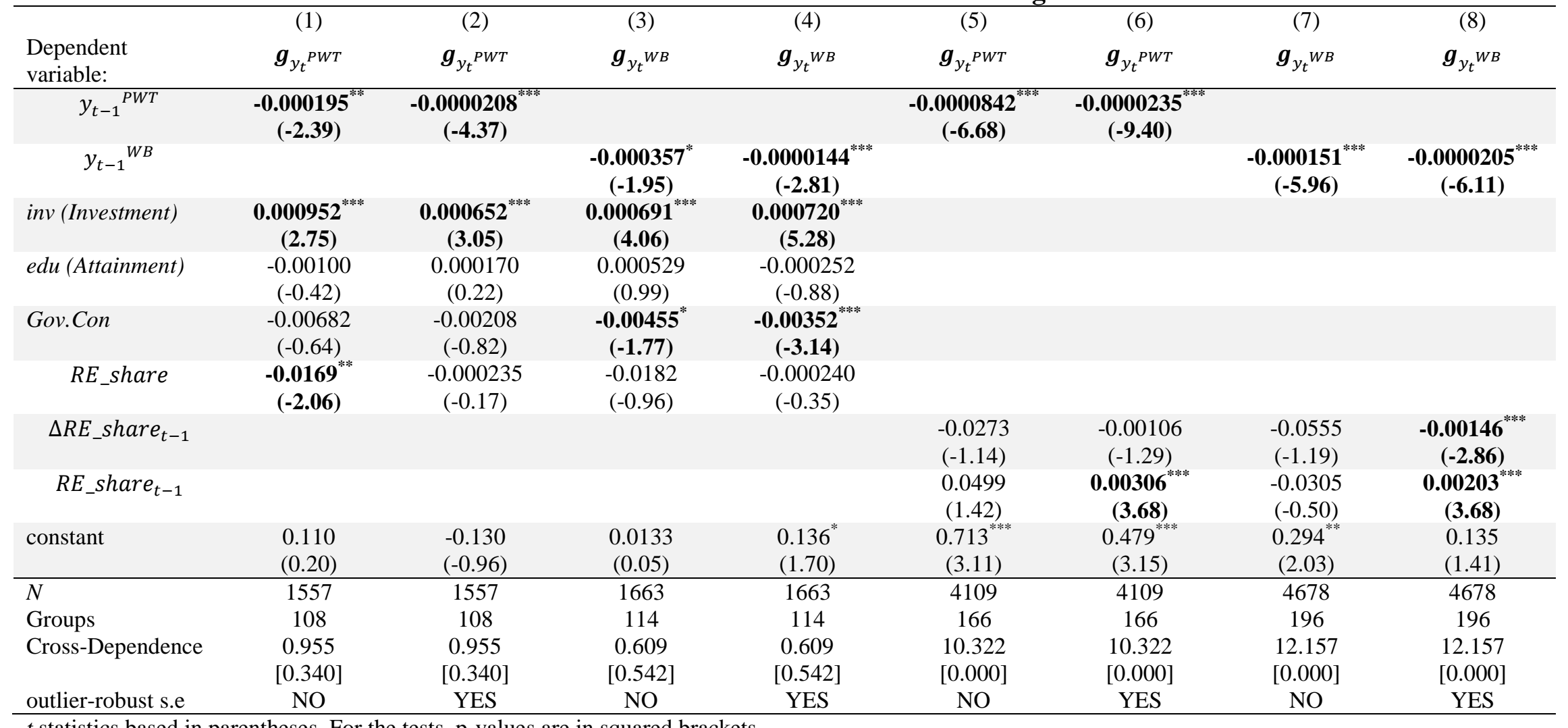

$t$ statistics based in parentheses. For the tests, $\mathrm{p}$-values are in squared brackets

${ }^{*} p<0.1,{ }^{* *} p<0.05,{ }^{* * *} p<0.01$. Significant results are highlighted in bold. 
In Table 4, columns (1) and (2) present a common correlated effect (CCE) regression with the dependent variable coming from the PWT, which presents the typical convergence effect (countries with lower income tend to grow faster, ceteris paribus), as well as the typical positive effect of physical capital accumulation and the negative effect of government consumption. Those effects are also consistent with the signs obtained for the income regressions in Table 2. Moreover in regression in column (1) the effect of renewable energy share in energy consumption is significantly negative while in regression presented in column (2) it is nonsignificant. Regressions in columns (3) and (4) change the dependent variable for the growth rate of GDP per capita coming from the World Bank, and results again suggest the non-significance of renewable energy share in energy consumption, maintaining the significance of results for the other variables that were already obtained in columns (1) and (2). Note that a cross-dependence test on residuals does not reject the null of crossindependence, meaning that the common correlated effects estimation is eliminating the effect that cross-correlation related inconsistency.

In columns (5) to (8) we re-specify the model to an error correction structure in order to allow to test for (Granger-) causality. Note that we noted earlier that per capita GDP and the renewable energy share are both I(1) and cointegrated. This is confirmed by the negative and highly-significant sign of the lag of GDP per capita in regressions presented in columns (5) to (8). Additionally, we have tested the residuals from this regression and all the tests (with and without trend) reject the null of nonstationarity which validates the ECM approach. In this case, results indicate that we may have a short-run negative effect of renewable energy consumption in economic growth (just in column 8) but a long-run positive effect on the long-run (in columns 6 and 8). It should be noted that in these ECM results, residuals crossindependence is clearly rejected, which means that those results are hit by inconsistency and should be taken with caution. However, when compared with the level of cross-dependence shown in the dependent variables (the test statistic for GDP per capita from PWT is 72.72 and for GDP per capita from WB is 59.29 - see Table A1 in the Appendix), those revealed by the residuals are much lower. Thus the potential inconsistency of the estimates with an ECM without common factors would be much bigger than the inconsistency that affects the presented results in Table 8, columns (5) to (8).

To sum up our results present either negative or nonsignificant influence of the share of renewable energies consumption to economic growth and income both with more traditional 
fixed-effects panel estimators and with methods that allow for heterogeneity and common effects amongst countries. If there is a positive result this may be only seen on the long-run.

\section{Conclusion}

Sustainability and the use of renewable energies have become a worldwide public and scientific discussion. As a result, another question was arisen - how does the consumption of renewable energies effect the economic growth? Although the results on the energy-growth nexus have shown to be conflicting, it is visible that most of the contributions suggest that the impact is positive (examples of that are Singh et al. (2019) and Alper and Oguz (2016)).

With the aim of contributing to the previous literature on the issue, our study includes a database that covers all countries for a period range of 59 years (enabling much more observations so far) and more variables. We also include methods that are robust to common factors (e.g. common shocks) and heterogeneity of effects between different countries, which has been overlooked in previous contributions.

Our results present either significantly negative or nonsignificant influence of the share of renewable energies consumption to economic growth and income both with more traditional fixed-effects panel estimators and with methods that allow for heterogeneity and common effects amongst countries. Our error correction model that controls for (Granger-) causality points out a possible positive effect in the long-run.

At last, we contribute to the literature that relates the importance of consumption of renewable energies and income and growth differences among countries, highlighting a negative or non-significant effect. This calls for the attention of policy makers to be cautious to use renewable energies promoting policies as a growth-enhancing policy, at least in the short run.

\section{References}

Acemoglu, D., Johnson, S., \& Robinson, J. (2005). Institutions as thefundamental cause of long-run growth. In P. Aghion, \& S. Durlauf(Eds.).Handbook of Economic Growth(Vol. 1A, pp. 385-472).Amsterdam: North Holland.

Alper, A. \& Oguz, O. (2016). The role of renewable energy consumption in economic growth: Evidence from asymmetric causality. Renewable and Sustainable Energy Reviews, 60, 953-959. 
Armeanu, D. Ş., Vintilă, G. \& Gherghina, Ş. C. (2017). Does reneawable energy drive sustainable economic growth? Multivariative panel data evidence for EU-28 contries. Energies, 10(3), 381.

Bailey, N., G. Kapetanios, \& M. Pesaran. (2015). "Exponent of Cross-Sectional Dependence: Estimation and Inference." Journal of Applied Econometrics 31(6): 929960.

Barro, R. J. (1991). Economic Growth in a Cross Section of Countries. The Quarterly Journal of Economics, 106(2), 407-443.

Bhattacharya, M., Paramati, S. R., Ozturk, I. \& Bhattacharya, S. (2016). The effect of renewable energy consumption on economic growth: Evidence from top 38 countries. Applied Energy, 162, 733-741.

Burke, P., (2010). Income, resources, and electricity mix. Energy Econ. 32, 613-626.

Chang, T., Gupta, R., Inglesi-Lotz, R., Simo-Kengne, B. \& Smithers, D. (2015). Renewable energy and growth: Evidence from heterogeneous panel of G7 countries using ganger causality. Renewable and Sustainable Energy Reviews, 52, 1405-1412.

Eberhardt, M., and F. Teal. (2011). "Economics for Grumblers: A New Look At The Literature on Cross-Countrt Growth Empirics." Journal of Economic Surveys 25(1): 109-155.

Eberhardt, M. and A. Prebistero, (2015). "Public Debt and Growth: Heterogeneity and non-linearity." Journal of International Economics, 97 (1): 45-58.

Hall, R. and C. Jones (1999), "Why do Some Countries Produce So Much More Output Per Worker than Others?", The Quarterly Journal of Economics, 114(1): 83-116,

Inglesi-Lotz, R. (2016). The Impact of renewable energy consumption to economic growth: A panel data application. Energy Economics, 53, 58-63.

Kao, C. (1999). Spurious regression and residual-based tests for cointegration in panel data. Journal of Econometrics 90: 1-44.

Long, X., Naminse, E. Y., Du, J. \& Zhuang, J. (2012). Nonrenewable energy, renewable energy, carbon dioxide emissions and economic growth in China from 1952 to 2012. Renewable and Sustainable Energy Reviews, 52(2015), 680-688.

Marques, A. C. \& Fuinhas, J. A. (2012). Is renewable energy effective in promoting growth?. Energy Policy, 42, 434-442.

Ozturk, I. (2010). A literature survey on energy-growth nexus. Energy Policy, 38(1), 340-349.

Pesaran, M. (2004). "General Diagnostic Tests for Cross Section Dependence in Panels," IZA Discussion Papers 1240, Institute of Labor Economics (IZA).

Pesaran, M (2006). "Estimation and Inference in Large Heterogeneous Panels with a 
Multifactor Error Structure.” Econometrica 74 (4): 967-1012.

Pesaran, M. Hashem (2007). "A simple panel unit root test in the presence of crosssection dependence." Journal of applied econometrics 22.2: 265-312.

Pesaran, M (2015). "Testing Weak Cross-Sectional Dependence in Large Panels." Economic Reviews 34 (6-10): 1089-1117.

Ramalho, E., Sequeira, T. \& M. Santos (2018). The effect of income on the energy mix: Are democracies more sustainable?, Global Environmental Change, 51, 10-21,

Sequeira, T.N., (2017). "Democracy and income: taking parameter heterogeneity and cross-country dependency into account". The B.E. Journal of Macroeconomics 17(2): 1935-1960.

Singh, N., Nyuur, R. \& Richmond, B. (2019). Renewable energy development as a driver of economic growth: Evidence from multivariate panel data analysis. Sustainability, 11(8), 2418.

Westerlund, J. (2005). New simple tests for panel cointegration. Econometric Reviews 24: 297-316.

\section{Appendix}

Table A1. Unit Root, Cointegration and Cross-Dependence tests

\begin{tabular}{|c|c|c|c|}
\hline \multicolumn{4}{|c|}{ Pesaran (2007) Panel Unit Root test (CIPS) - pvalues } \\
\hline & Lag 0 & Lag 1 & Lag 2 \\
\hline SHARE & 0.761 & 0.680 & 0.992 \\
\hline y_PWT & 1.000 & 1.000 & 1.000 \\
\hline $\mathrm{y}_{-} \mathrm{WB}$ & 1000 & 1.000 & 1.000 \\
\hline$\triangle$ SHARE & 0.000 & 0.000 & 0.000 \\
\hline$\Delta$ y_PWT & 0.000 & 0.000 & 0.000 \\
\hline$\Delta \mathrm{y}_{-} \mathrm{WB}$ & 0.000 & 0.000 & 0.000 \\
\hline \multicolumn{4}{|c|}{ Cointegration Tests } \\
\hline \multicolumn{4}{|c|}{ Kaо (1999) } \\
\hline & DF & $\mathrm{ADF}$ & \\
\hline SHARE-y_PWT & $-4.592 * * *$ & $13.80 * * *$ & \\
\hline SHARE-y_WB & $4.297 * * *$ & -1.174 & \\
\hline \multicolumn{4}{|c|}{ Westerlund (2005) } \\
\hline \multicolumn{4}{|c|}{ Variance Ratio } \\
\hline \multicolumn{4}{|l|}{ SHARE-y_PWT } \\
\hline \multicolumn{4}{|c|}{ Pesaran (2015) test for weak cross sectional dependence } \\
\hline SHARE & $26.62 * * *$ & & \\
\hline y_PWT & $72.72 * * *$ & & \\
\hline y_WB & $59.29 * * *$ & & \\
\hline $\boldsymbol{g}_{y_{t} P W T}$ & $42.97 * * *$ & & \\
\hline $\boldsymbol{g}_{y_{t} W B}$ & $52.43 * * *$ & & \\
\hline
\end{tabular}

Notes: specifications of tests with trends yields the same results and are available upon request. 